\title{
ArcheoSciences
}

Revue d'archéométrie

\section{Archaeometric analyses of Early and Middle Neolithic pottery from the Pian del Ciliegio rock shelter (Finale Ligure, NW Italy)}

Analyses archéométriques de céramiques du Néolithique ancien et moyen de l'abri de Pian del Ciliegio (Finale Ligure, Italie du Nord)

Claudio Capelli, Roberto Cabella, Angiolo Del Lucchese, Michele Piazza and Elisabetta Starnini

\section{OpenEdition}

\section{Journals}

\section{Electronic version}

URL: https://journals.openedition.org/archeosciences/1023

DOI: 10.4000/archeosciences. 1023

ISBN: 978-2-7535-1597-0

ISSN: $2104-3728$

\section{Publisher}

Presses universitaires de Rennes

\section{Printed version}

Date of publication: 31 December 2008

Number of pages: $115-124$

ISBN: 978-2-7535-0868-2

ISSN: 1960-1360

Electronic reference

Claudio Capelli, Roberto Cabella, Angiolo Del Lucchese, Michele Piazza and Elisabetta Starnini,

"Archaeometric analyses of Early and Middle Neolithic pottery from the Pian del Ciliegio rock shelter (Finale Ligure, NW Italy)", ArcheoSciences [Online], 32 | 2008, Online since 31 December 2011, connection on 01 February 2022. URL: http://journals.openedition.org/archeosciences/1023 ; DOI: https://doi.org/10.4000/archeosciences.1023 


\title{
Archaeometric analyses of Early and Middle Neolithic pottery from the Pian del Ciliegio rock shelter (Finale Ligure, NW Italy)
}

\author{
Analyses archéométriques de céramiques du Néolithique ancien et moyen de l'abri \\ de Pian del Ciliegio (Finale Ligure, Italie du Nord)
}

\author{
Claudio Capelli*, Roberto Cabella*, \\ Angiolo Del Lucchese**, Michele Piazza* and Elisabetta Starnini**
}

\begin{abstract}
The Neolithic site of Pian del Ciliegio is a rock shelter located in the Ponci Valley, at $220 \mathrm{~m}$ asl, in the Finalese (Liguria, NW Italy), a well-known karstic area characterised by the existence of several caves with prehistoric occupation. Archaeometric investigations (by optical microscopy and XRPD) were carried out on pottery samples mostly belonging to the Square-Mouthed Pottery Culture and the Impressed Ware Culture found out in the recent excavations of this site. Several fabrics were distinguished among the Square-Mouthed Pottery Culture pottery, suggesting different raw materials sources and production techniques. However, the nature of the mineral inclusions indicates in all cases local or circum-local production (e.g. within a range of a maximum of a few ten kilometres). All Square-Mouthed Pottery fabrics, in fact, contain elements that can be referred to the Palaeozoic metamorphic rocks outcropping in the area. In most cases they are associated with angular sparry calcite inclusions, possibly added as temper, which is a typical feature of other Neolithic pottery production from cave contexts studied in the area. On the contrary the Impressed Ware, although represented by a few sherds, shows a great variability both in fabrics and raw material provenance. Together with different local fabrics (with metamorphites \pm calcite), fabrics with ophiolitic inclusions (possibly from Tuscany) and volcanic temper (from Central Italy) were found too. These data confirm and integrate those resulting from the investigation of the neighbouring Arene Candide cave site: a long-distance movement by sea of people and goods, pottery included, during the Early Neolithic is now clearly demonstrated.
\end{abstract}

Résumé : Le site de Pian del Ciliegio est un abri situé à environ $220 \mathrm{~m}$ au-dessus du niveau de la mer dans la vallée du Ponci, qui se trouve dans le Finalese (Ligurie, Italie du nord-ouest), région bien connue par ses nombreuses grottes occupées durant le Néolithique. Plusieurs échantillons de céramiques de la Culture des Vases à Bouche Carrée et de la Culture à Céramique Imprimée (ou Impressa), retrouvées durant les fouilles du site, ont étés analysés par microscopie optique et diffraction de rayons X. Les différents groupes de pâte distingués parmi les céramiques de la Culture des Vases à Bouche Carrée signalent la présence de plusieurs sources de matières premières et de techniques de production. Toutefois, la nature des dégraissants indique en tout cas des productions locales ou circumlocales (c’est-à-dire, entre quelques dizaines de kilomètres maximum). En effet, toutes les pâtes de ces céramiques montrent des inclusions qui peuvent être rattachées aux roches métamorphiques Paléozoïques du Finalese. Très souvent, elles sont associées à de la calcite spathique, probablement ajoutée intentionnellement, qui est une caractéristique des pâtes d'autres productions néolithiques locales. La Céramique Imprimée (ou Impressa), au contraire, même si elle est très peu représentée, montre une grande variabilité en ce qui concerne les pâtes et les zones d'origine. Au côté de différentes pâtes locales (à inclusions de roches métamorphiques \pm calcite), on trouve aussi des pâtes à dégraissant ophiolitique (probablement de la Toscane) ou volcanique (de l'Italie centrale). Ces résultats confirment et intègrent les données sur la grotte voisine des Arene Candide: il est maintenant démontré un mouvement de personnes et de biens sur de longues distances, par voie maritime, durant le Néolithique ancien.

Key words: Archaeometric analyses, Liguria, Middle and Early Neolithic pottery, Northern Italy, Thin section, X-ray diffraction.

Mots clés : Analyses archéométriques, céramique du Néolithique ancien et moyen, diffraction de rayons X, Italie du Nord, Lames minces, Ligurie.

* Università di Genova, Dipartimento per lo Studio del Territorio e delle sue Risorse, Corso Europa 26, 16132 Genova (Italy). (capelli@dipteris.unige.it)

** Soprintendenza per i Beni Archeologici della Liguria, via Balbi 10, 16126 Genova (Italy). (elisabetta.starnini@beniculturali.it) 


\section{INTRODUCTION AND METHODS}

The Neolithic site of Pian del Ciliegio is a rock shelter located in the Val Ponci at 220 metres a.s.l. near Finale Ligure (SV), in the Finalese (NW Italy), a well-known karstic area characterized by the presence of several caves, many of which with traces of prehistoric occupation (Fig. 1; Bernabò Brea, 1947; Giuggiola \& Imperiale, 1970).

The Finalese area is part of the Ligurian Alps and is mainly composed of Miocenic and Triassic carbonate rock formations (nos. 3 and 5 in Fig. 1) and of Carboniferous and Permian meta-sediments and meta-volcanites (nos. 7 and 8 in Fig. 1) (Vanossi et al., 1984; Giammarino et al., 2002).

The rock shelter opens up at the base of a rock spur generated by selective karst corrosion and rockfall and it is located along the slope of the small valley of a permanent stream (Biancotti et al., 1990). The shelter is cut in the middle Miocene bioclastic limestone of the Mt. Cucco Member of the Finale Ligure Limestone ("Pietra di Finale"), that outcrops also in the surrounding area and unconformably overlies the middle Triassic San Pietro dei Monti Dolostone (Boni et al., 1968; Biancotti et al., 1990).

The excavations carried out from 1992 to 1997 by the Soprintendenza Archeologica della Liguria explored 23 square metres and brought to light 4.5 meters of stratigraphy with anthropogenic deposits which can be dated to the beginning of the Middle Neolithic by the presence of characteristic pottery and material culture remains (Del Lucchese, 1996). Absolute chronology obtained by 4 radiocarbon dates on individual charcoals indicate an occupation of the shelter during the first half of the 6th millennium uncal BP (Table 1), confirming the relative chronology based on stylistical evaluations.

The archaeological evidence, as well as the geoarchaeological and sedimentological analyses, suggest a seasonal (summer/autumn) occupation of the site, probably for animal husbandry (Del Lucchese, in press). It is worthy of note that the shelter has been used for pastoral purposes also in more recent historical times, as testified by the survival of corrals made of dry stone walls.

A total of some 5000 ceramic sherds have been collected in the stratigraphy during the archaeological excavations. Most of them belong to the early phase (the so-called "Finale-Quinzano" phase) of the Square-Mouthed Pottery Culture (Biagi, 1972).

Eight sherds of the Early Neolithic Impressed Ware Culture and one rim sherd of a typical Chassey Culture bowl were discovered in secondary position during the excavations of the Middle Neolithic deposit. Because no anthropogenic layer related to both the Impressed Ware Culture and the

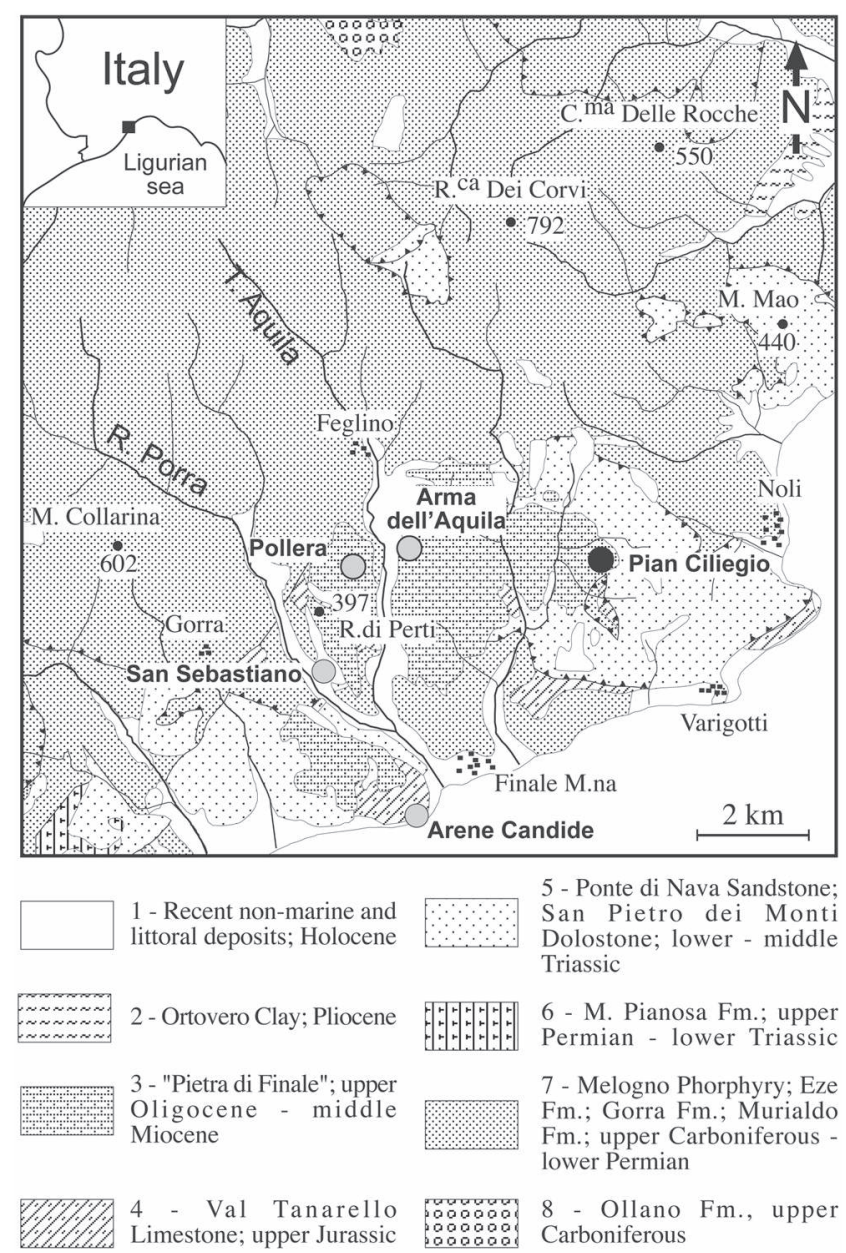

Figure 1: Geological sketch map of the Finalese area with the location of the Pian del Ciliegio rock shelter and some other important prehistoric sites known in the area (modified from Capelli et al., 2006c).

Figure 1 : Schéma géologique du Finalese montrant la localisation de l'Abri de Pian del Ciliegio et d'autres sites néolithiques importants connus dans la région.

Chassey Culture was documented in the shelter stratigraphy, the sporadic presence of the above mentioned sherds might witness at least the occupation of the area in the immediate surroundings of the rock shelter from the Early Neolithic up to the Late Neolithic.

Pian del Ciliegio is important because its deposit revealed only a single period of human activity, which is quite uncommon for the area under study. According to both the absolute chronology (Table 1) and the typology of artefacts, the period of habitation of the shelter lasted some centuries, corresponding to the very beginning of the Square-Mouthed Pottery Culture and the development of its first phase (Biagi, 1972). Therefore, it is possible to shed light both on the 


\begin{tabular}{|l|l|c|l|l|}
\hline \multicolumn{1}{|c|}{ sample no. -archaeological context } & \multicolumn{1}{|c|}{ Laboratory number } & uncal date & \multicolumn{1}{c|}{ cal BC } & \multicolumn{1}{c|}{ dated material } \\
\hline RPC 94 - US 40 (pit filling) & Beta-77355 & $5560 \pm 130$ BP & $4704-4222$ & individual charcoal \\
\hline RPC 94 - US 54 (occupation layer) & Beta-77356/ETH 13181 (AMS) & $5810 \pm 70 \mathrm{BP}$ & $4806-4497$ & individual charcoal \\
\hline RPC 96 - US 112b (rubbish deposit) & GX-22458 & $5990 \pm 250 \mathrm{BP}$ & $5383-4361$ & individual charcoal \\
\hline RPC 97 - US 165c (fireplace) & Beta-109796 (AMS) & $6000 \pm 60 \mathrm{BP}$ & $5038-4758$ & individual charcoal \\
\hline
\end{tabular}

Table 1: List of the radiocarbon dates from Pian del Ciliegio.

Tableau 1 : Liste des dates ${ }^{14} \mathrm{C}$ de Pian del Ciliegio.

origin of this Culture and the transition phase between the Early and Middle Neolithic in the region.

Within this perspective, archaeometric analyses were carried out in order to characterise the early Square-Mouthed pottery production from both a compositional and technical point of view and to obtain information about the provenance of the raw materials.

After the examination of the whole pottery assemblage by a 10X magnifying lens and a stereomicroscope, 37 samples (27 sherds representative of typological and fabric variability of the Square-Mouthed pottery production, 1 sherd with impressions pivotant -a characteristic Epicardial decoration-, all the 8 impressed ware fragments of the Early Neolithic, and 1 Chassey Culture rim sherd; Table 2), were submitted for the thin section analyses. Moreover, XRPD analyses were performed on a more restricted number of significant samples, which includes also the Impressed Ware.

XRPD analyses were carried out using a Philips PW3710 diffractometer. Powdered samples were run between $2.5^{\circ}$ and $70^{\circ} 2 \theta$, with a generator potential of $30 \mathrm{kV}$, a generator current of $22 \mathrm{~mA}$ (using a CuKo radiation), a Ni filter, and a scan speed of $1 \% \mathrm{~min}$. The software used for XRPD data reduction was Philips PC-APD Diffraction Software and MacDiff 3.0.6c.

Five samples of different local sediments representing possible raw materials for pottery production were also analysed in thin section for comparison. Three of them (nos. $5738,5739,5740)$ were collected inside the rock-shelter, one (5742) is a possible alluvial sediment of the local stream, and the last one (5741) is a red clay recovered in a fracture in the limestones close to the rock-shelter.

Several groups and sub-groups of pottery fabrics have been identified, which are described below.

\section{Square-Mouthed Pottery (SMP) Culture}

Twenty-seven samples representative of the characteristic wares of the SMP Culture were analysed in thin section (Table 2).
They comprise all the ware categories observed at macroscopic level and different types of vessels, ranging from thinwalled $(1.5-3 \mathrm{~mm}$ ) shapes to large containers (Fig. 2) with thick walls (up to $1 \mathrm{~cm}$ ). Usually thin-walled shapes show fine-medium fabrics, but some very fine wares are represented by sherds up to $5.5 \mathrm{~mm}$ thick. The surfaces of the vessels are commonly burnished and smooth. Their colours are not homogeneous and range from dark greyish brown to reddish brown, often buff and with firing clouds. Sampling was designed in order to verify whether the macroscopic variability of the pottery production might be the result of a different use of raw materials and techniques.

Four main petrographic groups have been identified. Most sherds belong to the first one.

\section{Group SMP1 (calcite + metamorphites inclusions)}

Fabrics are characterised by abundant non-plastic inclusions formed by two components with variable relative ratios (Fig. 3, nos. 1-3): i) angular sparry calcite, rarely characterised by light and dark parallel laminae couplet (speleothem carbonate; Fig. 3, n. 3); ii) subangular acid and subordinate basic metamorphic rock fragments and derived minerals (mainly quartz, mica and feldspar). Two sub-groups can be distinguished: in the first one (SMP1.1), inclusions are medium- to coarse-grained (up to a few $\mathrm{mm}$ in size) and can be interpreted as added temper (Fig. 3, n. 1); in the second one (SMP1.2), inclusions are fine-grained (mostly $<0.3 \mathrm{~mm}$, max $0.6 \mathrm{~mm}$ in size) and mainly composed of single mineral grains (Fig. 3, n. 2). The textural features seem to exclude a separate origin of the two components.

XRPD analyses of 3 representative samples of Group 1 with different granulometric features (7068, 7070, 7079) have been carried out. All diffractograms show similar patterns (Fig. 4), with quartz, calcite, albitic plagioclase feldspar and illite/muscovite peaks; traces of dolomite in 7068 and rutile in 7979 were also found out.

The stability of both calcite (from temper) and phyllosilicates (probably both illite from clay matrix as well as mica from temper) points to firing temperatures below ca. $900^{\circ} \mathrm{C}$ (Cultrone et al., 2001). 


\begin{tabular}{|c|c|c|c|c|c|c|}
\hline Group & $\begin{array}{l}\text { sample } \\
\text { no. }\end{array}$ & $\begin{array}{l}\text { inventory } \\
\text { US/square }\end{array}$ & description & Culture & Period & Fig. \\
\hline SMP1.1 & 7063 & RPC96 US78 C10 & body sherd, $2.2 \mathrm{~cm}$ thick, coarse ware & SMP & MN - early phase & $3, \mathrm{n} .1$ \\
\hline SMP1.1 & 7064 & RPC94/17 US80 H1 & body sherd, $9 \mathrm{~mm}$ thick, coarse ware & SMP & MN - early phase & 3, n. 3 \\
\hline SMP1.1 & 7065 & RPC94/8 US6 & body sherd, $6 \mathrm{~mm}$ thick, medium ware & SMP & MN - early phase & - \\
\hline SMP1.1 & 7066 & RPC94/6 US7 C12 7b & body sherd, $8 \mathrm{~mm}$ thick, medium ware & SMP & MN - early phase & - \\
\hline SMP1.1 & 7067 & RPC94/13 US7 C12 & body sherd, $5 \mathrm{~mm}$ thick, medium ware & SMP & MN - early phase & - \\
\hline SMP1.1 & 7068 & RPC94/7 US9 D12 & body sherd, $5.5 \mathrm{~mm}$ thick, medium-coarse ware & SMP & MN - early phase & - \\
\hline SMP1.1 & 7069 & RPC94/2 US21 & body sherd, $7 \mathrm{~mm}$ thick, medium ware & SMP & MN - early phase & - \\
\hline SMP1.1 & 7070 & RPC94/1 US46 & body sherd, $5 \mathrm{~mm}$ thick, medium-coarse ware & SMP & MN - early phase & - \\
\hline SMP1.1 & 7071 & RPC94/11 US54 & body sherd, $6 \mathrm{~mm}$ thick, medium ware & SMP & MN - early phase & - \\
\hline SMP1.1 & 7072 & RPC94/3 US73 & body sherd $5 \mathrm{~mm}$ thick, coarse ware & SMP & MN - early phase & - \\
\hline SMP1.1 & 7073 & RPC96 US78 C10 (5) & rim sherd $1 \mathrm{~cm}$ thick, coarse ware & SMP & MN - early phase & - \\
\hline SMP1.1 & 7074 & RPC94/4 US578 C12 & body sherd $7 \mathrm{~mm}$ thick, medium ware & SMP & MN - early phase & - \\
\hline SMP1.1 & 7075 & RPC96 US78 C10 (6) & rim sherd $3 \mathrm{~mm}$ thick, medium ware & SMP & MN - early phase & - \\
\hline SMP1.1 & 7976 & RPC94/14 US65 & body sherd $3 \mathrm{~mm}$ thick, medium ware & SMP & MN - early phase & - \\
\hline SMP1.1 & 7977 & RPC94/10 US89 & body sherd $4 \mathrm{~mm}$ thick, medium ware & SMP & MN - early phase & - \\
\hline SMP1.2 & 7978 & RPC94/15 US52 & body sherd $6 \mathrm{~mm}$ thick, medium ware & SMP & MN - early phase & - \\
\hline SMP1.2 & 7979 & RPC94/16 US69 & body sherd $6 \mathrm{~mm}$ thick, medium-fine ware & SMP & MN - early phase & 3, n. 2 \\
\hline SMP2 & 7980 & RPC94/5 US15 & body sherd $5.5 \mathrm{~mm}$ thick, fine ware & SMP & MN - early phase & - \\
\hline SMP2 & 7981 & RPC95 US112 C12 & body sherd $5 \mathrm{~mm}$ thick, fine ware & SMP & MN - early phase & 3, n. 4 \\
\hline SMP2 & 7982 & RPC96 US639 CP10 & body sherd $3 \mathrm{~mm}$ thick, fine (pseudo-figulina) ware & SMP & MN - early phase & - \\
\hline SMP3 & 7983 & RPC94/18 US32 & body sherd $1.5 \mathrm{~mm}$ thick, fine ware & SMP & MN - early phase & - \\
\hline SMP3 & 7984 & RPC94/12 US75 CP10 & body sherd $7 \mathrm{~mm}$ thick, coarse ware & SMP & MN - early phase & - \\
\hline SMP3 & 7985 & RPC94/9 US34 & body sherd $6 \mathrm{~mm}$ thick, medium-coarse ware & SMP & MN - early phase & - \\
\hline SMP3 & 7986 & RPC96 US106 B10 & rim sherd $6 \mathrm{~mm}$ thick, coarse ware & SMP & MN - early phase & - \\
\hline SMP3 & 7987 & $\begin{array}{l}\text { RPC97 US165 } \\
\text { RCO10-12 }\end{array}$ & rim sherd $6.5 \mathrm{~mm}$ thick, coarse ware & SMP & MN - early phase & 3, n. 5 \\
\hline SMP3 & 7988 & RPC97 BLO US109b & body sherd $6 \mathrm{~mm}$ thick, coarse ware & SMP & MN - early phase & - \\
\hline SMP4 & 7989 & RPC94/19 US85 F & body sherd $3 \mathrm{~mm}$ thick, fine ware & SMP & MN - early phase & 3, n. 6 \\
\hline IW1 & 8059 & $\begin{array}{l}\text { RPC96 US130 E11+ } \\
\text { US137 E10 } 90417\end{array}$ & $\begin{array}{c}\text { body sherd } 7.5 \mathrm{~mm} \text { thick, impressed decoration, coarse } \\
\text { ware }\end{array}$ & IW & Early Neolithic & $\begin{array}{l}\text { 6, n. } 1 \\
5, \text { n. } 1\end{array}$ \\
\hline IW2 & 7062 & RPC96 US139 & $\begin{array}{l}\text { body sherd } 12 \mathrm{~mm} \text { thick, plastic cordon, reddish } \\
\text { brown, burnished surfaces, medium-coarse ware }\end{array}$ & IW & Early Neolithic & - \\
\hline IW2 & 8058 & RPC 90450 & $\begin{array}{c}\text { body sherd } 8 \mathrm{~mm} \text { thick, plastic cordon, medium-coarse } \\
\text { ware }\end{array}$ & IW & Early Neolithic & 5, n. 4 \\
\hline IW2 & 7991 & RPC96 D10 90418 & body sherd $8 \mathrm{~mm}$ thick, incised decoration, coarse ware & Epicardial & Early Neolithic & 6, n. 2 \\
\hline IW3 & 8056 & $\begin{array}{l}\text { RPC94 US133+US41 } \\
90416\end{array}$ & $\begin{array}{c}\text { body sherd } 6.5 \mathrm{~mm} \text { thick, impressed decoration, coarse } \\
\text { ware }\end{array}$ & IW & Early Neolithic & 5, n. 3 \\
\hline IW3 & 7061 & RPC95 C13 91 & $\begin{array}{l}\text { body sherd } 10 \mathrm{~mm} \text { thick, plastic cordon, dark grey, } \\
\text { smoothed surfaces, medium ware }\end{array}$ & IW & Early Neolithic & 6, n. 3 \\
\hline IW4 & 8057 & RPC94 90443 & $\begin{array}{c}\text { body sherd } 10 \mathrm{~mm} \text { thick, impressed decoration, } \\
\text { medium-coarse ware }\end{array}$ & IW & Early Neolithic & $\begin{array}{l}5, \text { n. } 2 \\
6, \text { n. } 4\end{array}$ \\
\hline IW5 & 8060 & $\begin{array}{l}\text { RPC94 US83 F11 saggio } \\
\text { sud }\end{array}$ & $\begin{array}{c}\text { body sherd } 10 \mathrm{~mm} \text { thick, impressed decoration, } \\
\text { medium ware }\end{array}$ & IW & Early Neolithic & $\begin{array}{l}5, \text { n. } 6 \\
6, \text { n. } 5\end{array}$ \\
\hline IW6 & 7060 & RPC94 US75 90415 & $\begin{array}{l}2 \text { body sherds } 7.5 \mathrm{~mm} \text { thick, impressed decoration, } \\
\text { dark greyish brown worn surfaces, coarse ware }\end{array}$ & IW & Early Neolithic & $\begin{array}{l}5, \text { n. } 5 \\
7, \text { n. } 6\end{array}$ \\
\hline $\mathrm{CH} 1$ & 7990 & RPC 18 & rim sherd, black burnished, fine ware & Chassey & Late Neolithic & - \\
\hline
\end{tabular}

Table 2: List of the analysed pottery samples from Pian del Ciliegio. IW: Impressed Ware; MN: Middle Neolithic; SMP: Square Mouthed Pottery.

Tableau 2 : Liste des échantillons analysés. IW: Céramique Imprimée (ou Impressa). MN : Néolithique Moyen; SMP : Vases à Bouche Carrée. 


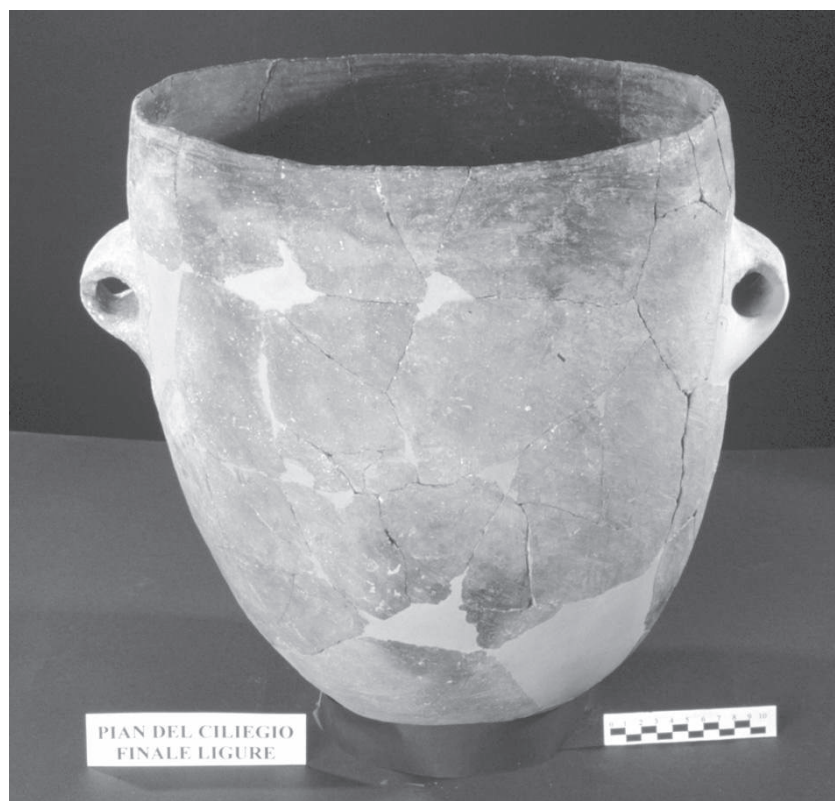

Figure 2: Middle Neolithic, Square-Mouthed Pottery large container from Pian del Ciliegio.

Figure 2: Grand vase de la Culture des vases à Bouche Carrée du Néolithique moyen retrouvé à Pian del Ciliegio.

The petrographic features of the inclusions suggest a Finalese production. Calcite is in fact common both in veins cutting the carbonate rock formations and in a cave environment. Moreover, the metamorphic inclusions are well consistent with the local Palaeozoic meta-sediments and meta-volcanic rocks (Fig. 1; Vanossi, 1991). However, the possibility of an origin of Group SMP1 from another Finalese site must be taken into account because of the lack of precise comparisons with the rocks and sediments outcropping in the area surrounding the shelter. Fabrics showing very similar features to Group SMP1.1 are described by Ferraris \& Ottomano (1997) among the sample of the SMP Culture from the Arene Candide cave.

\section{Groups SMP2-4 (metamorphic inclusions only)}

Only a few vessels of the SMP Culture show calcite-free fabrics (Fig. 3, nos. 4-6). Inclusions are generally abundant and medium- or coarse-grained (added temper). Most of them (Groups 2-3; Fig. 3, nos. 4-5) are composed of metamorphic elements (mainly quartz-micaschist fragments and quartz, mica and feldspar grains) mostly attributable to local or circum-local Palaeozoic formations (Fig. 1). However, a rather high variability in textural and compositional features was observed, pointing to the existence of several minor productions for which different raw material sources were exploited and manufacturing techniques adopted. At pre-
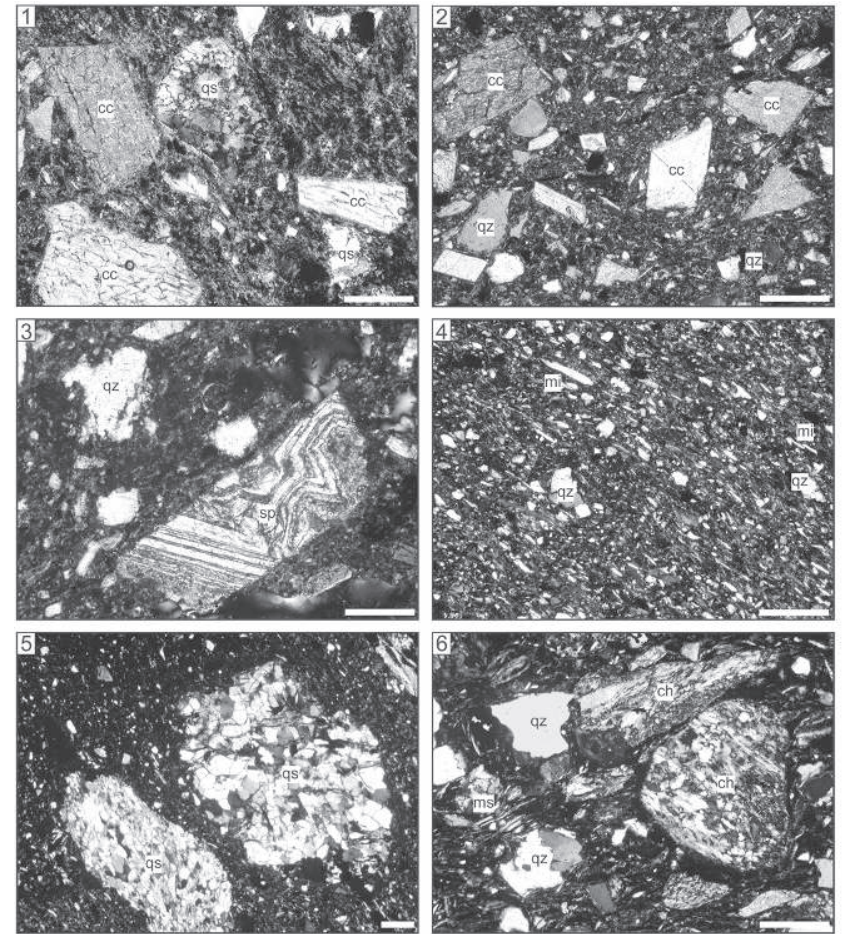

Figure 3: Microphotographs (crossed polars, scale bar: $0.2 \mathrm{~mm}$ ) of analysed samples of the Square Mouthed Pottery Culture: 1) 7063 (SMP1.1); 2) 7079 (SMP1.2); 3) 7064 (SMP1.1); 4) 7981 (SMP2); 5) 7987 (SMP3); 6) 7989 (SMP4). cc: sparry calcite; ch: chloritic schist; mi: mica; ms: micaschist; qs: quartzschist; qz: quartz; sp: speleothem.

Figure 3: Microphotographie d'échantillons de la Culture des Vases à Bouche Carrée analysés: 1) 7063 (SMP1.1); 2) 7079 (SMP1.2); 3) 7064 (SMP1.1); 4) 7981 (SMP2); 5) 7987 (SMP3); 6) 7989 (SMP4). cc: calcite spathique; ch: schiste chloritique; mi: mica; ms: micaschiste; qs: quartzschiste; qz: quartz; sp: spéléothème.

sent, the only case of a possible very local production is represented by 7988 (SMP3), which shows similarity with the Fe-rich clay sample 5741.

Finally, the Group 4 sample (Fig. 3, n. 6) is rich in inclusions derived from gneisses, metabasites (chlorite \pm albite \pm epidote) and serpentinites (?), which do not outcrop in the Finalese. A regional production cannot be excluded, because Palaeozoic rocks form the Loano, Calizzano, and Savona Massifs (the latter is in contact with the Jurassic ophiolites of the Montenotte Unit; Vanossi, 1991).

Also in the case of Groups SMP2-4, similarities could be found with some of the fabrics of the Arene Candide Middle Neolithic pottery described by Ferraris \& Ottomano (1997).

ArcheoSciences, revue d'archéométrie, 32, 2008, p. 115-124 


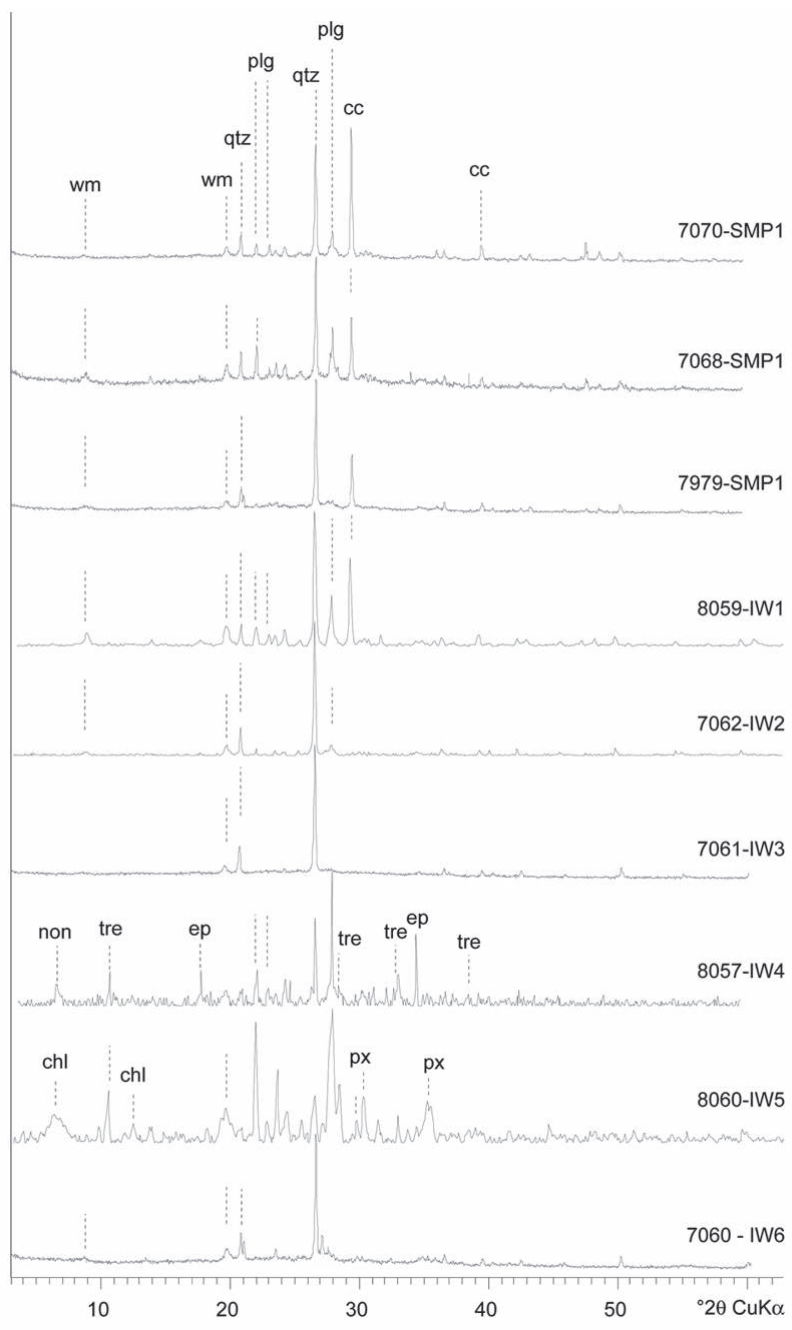

Figure 4: X-ray diffractograms of the analysed samples. cc: calcite; chl: chlorite; ep: epidote; non: nontronite; plg: plagioclase; px: pyroxene; qtz: quartz; tre: tremolite; wm: muscovite/illite.

Figure 4: Diffractogrammes des échantillons analysés. $c c$ : calcite; chl: chlorite; ep : epidote; non : nontronite; plg: plagioclase; px: pyroxène; qtz: quartz; tre : trémolite; wm : muscovite/illite.

\section{IMPRESSED WARE (IW) CULTURE}

\section{Typological data}

Thin section and XRPD analyses were carried out on all the 8 sherds of the IW Culture recovered in the excavations (Table 2), which comprise one body sherd decorated with rows of sequences of impressions made by an indented shell rim (7060; Fig. 5, n. 5), 3 sherds with a horizontal plastic cordon decorated with a sequence of implement impressions (7061, 7062, 8058; Fig. 5, n. 4), and 4 sherds decorated
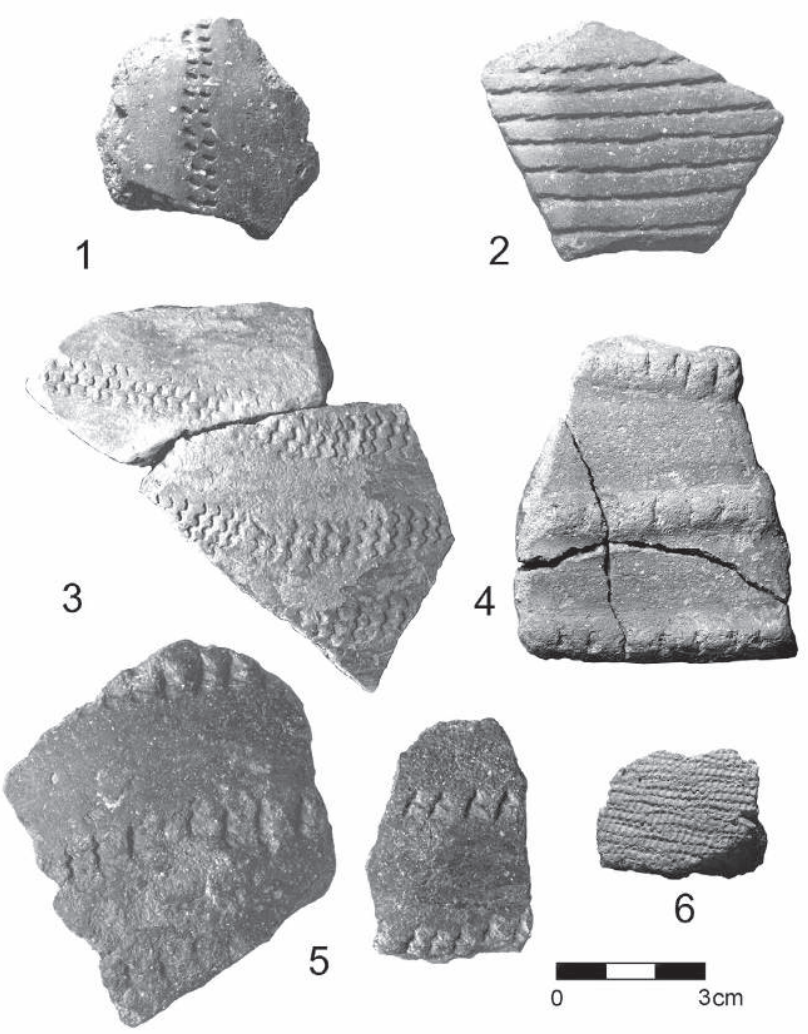

Figure 5: The analysed sherds of the Early Neolithic impressed ware (for the description see Table 2): 1) 8059; 2) 8057; 3) 8056; 4) 8058 ; 5) 7060; 6) 8060 (digital elaboration by S. Paba).

Figure 5: Les fragments de la Céramique Imprimée analysés : 1) 8059 ; 2) 8057 ; 3) 8056; 4) 8058; 5) 7060; 6) 8060 (élaboration numérique: S. Paba).

with other impressed motifs (8056, 8057, 8059, 8060; Fig. 5, nos. 1-3, 6). Moreover, one single body sherd (7991) with a "rocker" type of decoration, which might be attributable to a late Cardial phase, was also analysed.

\section{Fabric characterisation}

The IW samples can be divided into 6 groups of fabrics very different from each other.

\section{Group IW1: 8059}

Inclusions are abundant, well-sorted and coarse-grained (up to a few $\mathrm{mm}$ in size). They are formed by two different components sharing similar granulometric characteristics (Fig. 6, n. 1): i) angular to subangular fragments of acid metamorphic rocks (quartz+feldspar metamorphites with quartz+albite+epidote recrystallisation and rarer quartzschists) and derived single mineral grains; ii) subordinate 


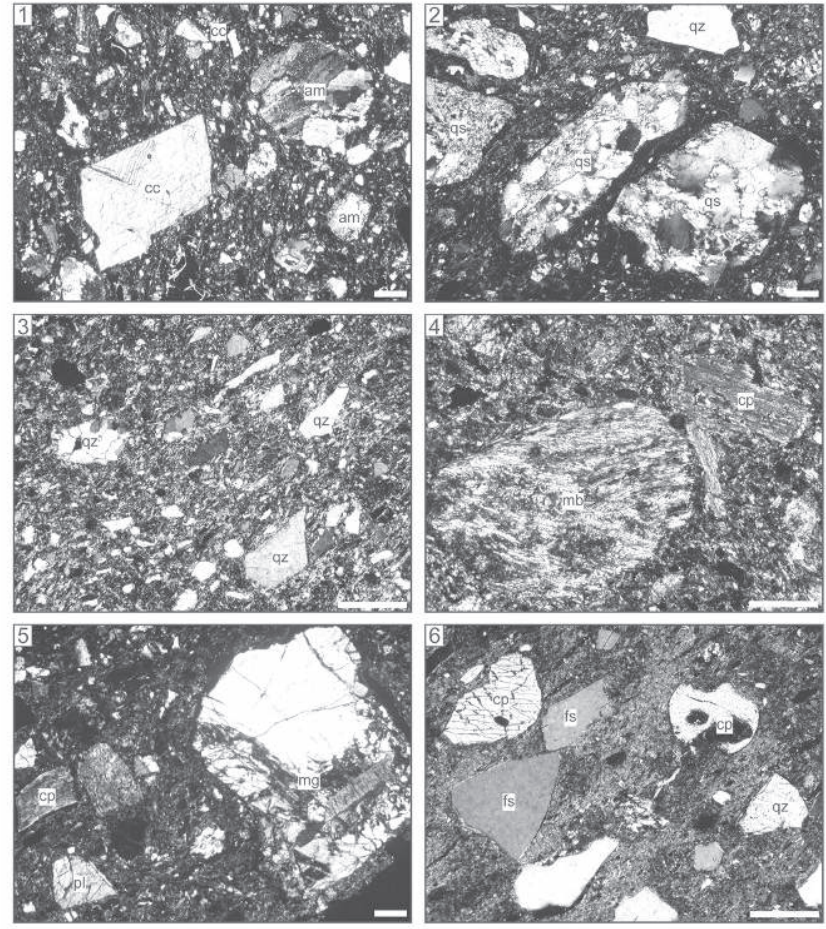

Figure 6: Microphotographs (crossed polars, scale bar: $0.2 \mathrm{~mm}$ ) of Impressed Ware analysed samples: 1) 8059 (IW1); 2) 7991 (IW2); 3) 7061 (IW3); 4) 8057 (IW4); 5) 8060 (IW5); 6) 7060 (IW6). am: acid metamorphite, cc: sparry calcite; cp: clinopyroxene; fs: feldspar; mb: metabasic rock; mg: metagabbro; pl: plagioclase; qs: quartzschist; qz: quartz.

Figure 6 : Microphotographies d'échantillons de céramique imprimée : 1) 8059 (IW1); 2) 7991 (IW2); 3) 7061 (IW3); 4) 8057 (IW4); 5) 8060 (IW5); 6) 7060 (IW6). am : amphibole, cc : calcite spathique; cp : clinopyroxène; $f s$ : feldspath; $m b$ : roche métabasique; $m g$ : métagabbro; pl: plagioclase; qs : quartzschiste; qz: quartz.

very angular sparry calcite crystals, sometimes speleothem carbonate fragments.

It seems probable that the non-plastic coarse inclusions were intentionally added; the textural features point to the presence of the two components in one raw material.

Quartz, calcite, albitic plagioclase, and illite/muscovite are the mineral phases identified by XRPD analyses (Fig. 4).

\section{Group IW2: 7062, 8058, 7991}

Temper inclusions are abundant, well sorted and coarsegrained (up to 1-2 mm size), mainly formed by quartzschist and quartz-micaschist fragments (Fig. 6, n. 2) and quartz, feldspar, and mica grains. Several heavy minerals (among which epidote and amphibole) are accessory in the groundmass.

Quartz, illite/muscovite and albitic plagioclase are the mineral phases identified by the XRPD analysis of sample 7062 (Fig. 4).

\section{Group IW3: 8056, 7061}

Inclusions are abundant and fine-grained (mainly $<0.2$ mm) (Fig. 6, n. 3). They are formed by quartz, feldspar, mica prevailing on several accessory minerals (sphene, epidote, amphibole) and rare metamorphic rock fragments.

Quartz and illite/muscovite are the mineral phases identified by the XRPD analysis of sample 7061 (Fig. 4).

\section{Group IW4: 8057}

Inclusions, very abundant and poorly-sorted, are formed by greenschist (meta-andesite: albite+epidote+amphibole with occasional relics of primary pyroxene and amphibole), micaschist and chloritic schist fragments (Fig. 6, n. 4), and derived mineral grains.

The mineral phases resulting from the XRPD analysis (Fig. 4) are: nontronite, tremolitic amphibole, quartz, albite, and epidote.

\section{Group IW5: 8060}

Temper inclusions are very abundant and coarse-grained. They are composed only of femic or ultra-femic elements (Fig. 6, n. 5): metagabbro, serpentinite, amphibolite rock fragments and derived plagioclase, clinopyroxene (also "diallage"), amphibole and ore individuals.

The mineral phases resulting from the XRPD analysis (Fig. 4) are: plagioclase, tremolitic amphibole, augitic clinopyroxene, and chlorite. No quartz peaks are present.

\section{Group IW6: 7060}

Non-plastic inclusions are abundant, medium-grained ( $<0.7 \mathrm{~mm}$ across), well-sorted and subangular to rounded. They probably derive from a marine sand added as temper. Volcanic elements (sanidine, plagioclase, clinopyroxene, rare ore minerals and sphene grains; often altered basaltic and trachitic rock fragments) are dominant on fine-grained sandstone, claystone, quartz-micaschist, chert fragments and metamorphic quartz and feldspar grains (Fig. 6, n. 6).

The mineral phases resulting from the XRPD analysis (Fig. 4) are: quartz, aegirinic-augitic clinopyroxene, illite/ muscovite, albitic plagioclase, K-feldspar.

\section{Discussion}

The analyses of the IW samples reveal high variability in raw material sources, production techniques, and provenance. Moreover, only some of the 6 groups can be referred to local productions. In any case, the thin section evidence and the results of XRPD analyses suggest relatively low firing temperatures $\left(<900^{\circ} \mathrm{C}\right)$ : in fact, phyllosilicates are always stable, sometimes associated with either calcite or amphibole. 
An origin from the Finalese is probable for Groups 1-4. The various metamorphic inclusions are well comparable to the Permo-Carboniferous acid metavolcanites, metasediments (IW1-3) and meta-andesites (Eze Formation; IW4) outcropping in the area. However, only in few cases a very local production can be hypothesised: in particular, 8058 (IW2.1), as well as 7988 (SMP3), shows similarity with the clay sample 5741. Fabrics rich in metamorphic temper and sparry calcitefree characterise the Impressed ware of the open-air site of San Sebastiano di Perti (Capelli et al., 2006c), but they are not completely similar to those of Pian del Ciliegio.

Particularly interesting is the close resemblance both in composition and texture between IW1 and SMP1.1 Groups (see above). Moreover, their fabrics are similar to those of several Impressed ware samples from the Arene Candide cave (Capelli et al., 2007b).

The remaining two samples/Groups (IW5-6) are characterised by inclusions incompatible with local/regional rocks.

The temper of IW5 can be related to the Apennine ophiolitic rocks, lacking Alpine metamorphism, outcropping (along the coast) in Eastern Liguria, Corse and Central Tuscany (Cortesogno et al., 1994). Fabrics with similar petrographic composition have also been found at the Arene Candide cave (Capelli et al., 2007b).

Finally, the provenance of the IW6 sample from the Tyrrhenian area (between southern Tuscany and Campania), which is characterised by alkali-potassic Plio-Pleistocene volcanic rocks (Conticelli et al., 1986), is undoubtedly suggested by the peculiar temper inclusions. However, a more restricted provenance from the northern part of that area might be more probable for two main reasons: a) geological-archaeometric one: recent studies on Roman pottery showed that the sedimentary and acid metamorphic components associated with the volcanic inclusions, related to the Apennine Units of Tuscany, could discriminate Tuscan productions from Latial-Campanian ones (Capelli et al., 2007a; Menchelli et al., 2007); b) archaeological one: the diffusion area of the IW Culture sites of upper- and medium Tyrrhenian facies extends southward comprising Tuscany and the Tuscan Archipelago, where IW production similar to that found in the Finalese area have been recently found (Boschian \& Gabriele, 2007).

\section{Chassey Culture Pottery}

One rim sherd recovered in a non-stratigraphic context can be attributable to the Chassey Culture from a typological point of view (typical shape, surface treatment and macroscopic characteristics of its fabric).

\section{Group CH1: sample 7990}

Non-plastic inclusions are relatively scarce, angular, moderately sorted and mostly fine-grained $(<0.2 \mathrm{~mm})$. They are mainly composed of mono- and polycrystalline quartz, mica and feldspar.

The metamorphic origin of the inclusions cannot exclude a local production. In any case, the fabric shows no comparison with other samples of the Chassey Culture from the Arene Candide cave analysed by Ferraris \& Ottomano (1997), the temper of which is rich in calcite or quartzite fragments. Moreover, no striking similarities can be found between $\mathrm{CH} 1$ fabric and the Chassey Culture pottery production of Abri Pendimoun (Castellar, France), recently investigated by Basso et al. (2006).

\section{Conclusions}

The occupation of the area surrounding the Pian del Ciliegio rock shelter since the Early Neolithic is inferred from the presence of the few sherds of IW collected in secondary position during the excavations of the deposit. Despite the low number of IW Culture sherds, archaeometric analyses allow us to recognise the presence of very different products, at least one of which is imported from long distance.

This latter discovery integrates the results of a recent archaeometric study on the Impressed ware found at the Arene Candide cave (Capelli et al., 2006a; 2006b; 2007b), located only a few kilometres away from the Pian del Ciliegio rock shelter (Fig. 1). In that cave, together with numerous local wares, several sherds with either gneiss or ophiolithic inclusions incompatible with the Finalese geology were found. They allowed us to formulate the hypothesis of a movement of people and/or wares along the upper Tyrrhenian coasts, with the most distant possible provenance area located in Central Tuscany (Capelli et al., 2007b). The presence at Pian del Ciliegio of one sherd with inclusions derived from the volcanic formations of centralsouthern Italy reinforces that hypothesis, extending southward the provenance area (Fig. 7). It is noteworthy that IW Culture pottery containing volcanic temper, imported from Southern Tuscany or Latium, was recently recognised also at Cala Giovanna Piano, in the Tuscan Archipelago (Muntoni, 2002; Boschian \& Gabriele, 2007; Nonza-Micaelli, 2007).

The results of this research demonstrate that archaeometric analyses of significant ceramic samples, combined with a detailed knowledge of the regional geology, could lead to a precise reconstruction of the circulation of ceramic containers during the Neolithic. However, relevant results can 


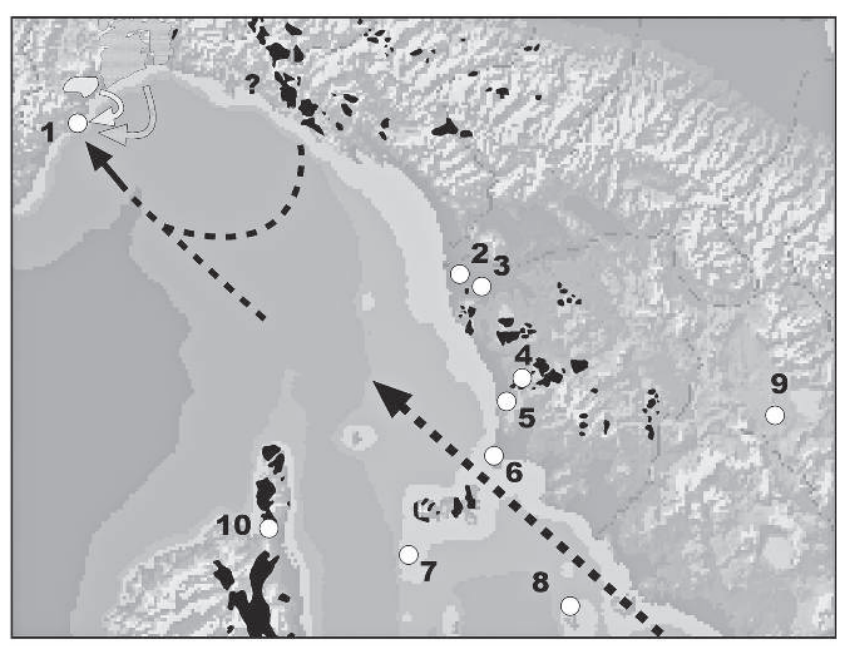

Figure 7: Cabotage routes along the central and upper Tyrrhenian coasts during the Early Neolithic, hypotesised from the results of the archaeometric analyses of the Impressed Ware (modified from Capelli et al., 2007b, Fig. 6). Black: poorly metamorphic ophiolites of Eastern Liguria, Tuscany, and Corse; dark gray: Voltri Group metaophiolites; light gray: Savona Palaeozoic basament; 1: Pian del Ciliegio, Finalese area; 2-10: some of the most important sites of the Early Neolithic known in the studied area (2: Coltano; 3: Podere Uliveto and Stagno; 4: Castagneto Carducci; 5: San Vincenzo; 6: Piombino; 7: Pianosa Island, Cala Giovanna Piano; 8: Giglio Island, Le Secche; 9: Pienza; 10: Strette).

Figure 7 : Routes de cabotage le long de la mer Thyrrénienne centrale et septentrionale durant le Néolithique ancien, suggérées par les résultats des analyses archéométriques de la Céramique Imprimée. Noir : ophiolites peu métamorphiques de la Ligurie orientale, Toscane et Corse; gris foncé : ophiolites métamorphiques du Group de Voltri; gris clair : socle Paléozoïque de Savone; 1 : Pian del Ciliegio, aire du Finalese; 2-10 : sites du Néolithique ancien dans l'aire étudiée (2: Coltano; 3 : Podere Uliveto et Stagno; 4: Castagneto Carducci; 5 : San Vincenzo; 6: Piombino; 7 : Ille de Pianosa, Cala Giovanna Piano; 8 : Ile du Giglio, Le Secche; 9 : Pienza; 10 : Strette).

be obtained only if the archaeologist and geologist together select the samples, during a careful study and examination of the pottery assemblage and its context.

It is now clear, contrary to the situation depicted for the Adriatic coast a few years ago (Spataro, 2002), that a complex network of navigation movement was connecting the Tyrrhenian coastal settlements already during the Early Neolithic.

Archaeometric evidence helps to explain the strong, stylistic similarities in pottery decorations of the IW observed within this macroregion, demonstrating that the circulation of goods involved not only stone resources (i.e. obsidian and "greenstones"), but also ceramics and, last but not least, people.

Some degree of continuity from the Early to the Middle Neolithic in pottery manufacture traditions and/or exploi- tation of the raw material sources could be suggested by similarities existing between a few SMP and IW fabrics. However, the Early SMP Culture pottery seems more homogeneous than the IW from a petrographic point of view. The former is characterised by one prevalent local production (fabrics with sparry calcite temper), whilst other minor local or circum-local production (fabrics with only metamorphic inclusions) is each represented only by one or few sherds. Certain long-distance imports were not found during this phase (a possible example could be the painted "figulina" ware, which was not analysed by optical microscopy due to the very fine-grained fabric and the consequent lack of diagnostic petrographic elements).

Finally, the textural and petrographic features observed in SMP1.1 and IW1 fabrics raise the question of the origin of the temper used for the main local production Groups. Sparry calcite is a quite common component in Neolithic pottery fabrics and is usually considered as an intentionally added temper (Basso et al., 2006; Laviano \& Muntoni, 2006). However, while some of the SMP Culture fabrics are calcite-dominated, in others, on the contrary, calcite individuals are rare. Moreover, in the same sample both calcite and metamorphic inclusions show the same granulometric features. In these latter cases, it is difficult to suppose that calcite temper was intentionally added as a separate component after artificial crushing of carbonate raw materials. It is, instead, more probable that a raw material naturally containing calcite was employed in the manufacture of such vessels. Alluvial sands of short-course torrents in the Finalese karstic environment could be a possible raw material source, but no field evidence have been found yet. To better define the picture, it will be necessary in the future to perform a more detailed field survey and to complete the study of the soil samples collected in the area.

\section{Acknowledgements}

This work has been carried out in the framework of the Research Cooperation Program for archaeometric analyses between the DIPTERIS and the Soprintendenza per i Beni Archeologici della Liguria. XRPD analyses were performed by A. Cucchiara.

\section{References}

Basso, E., Binder, D., Messiga, B. and Riccardi, M.P., 2006. The Neolithic pottery of Abri Pendimoun (Castellar, France): a petro-archaeometric study. In M. Maggetti, B. Messiga (eds.). Geomaterials in Cultural Heritage, Geological Society special publication 257, London, 33-48. 
Bernabò Brea, L., 1947. Le caverne del Finale. Itinerari storicoturistici, Istituto di Studi Liguri, Bordighera.

BIAGI, P., 1972. Il Neolitico di Quinzano veronese. Memorie del Museo Civico di Storia Naturale di Verona, XX: 413-485.

Biancotti, A., Brancucci, G. and Motta, M., 1990. Carta geomorfologica dell'Altopiano delle Manie e dei bacini idrografici limitrofi. Scala 1:20.000. Studio Cartografico Italiano, Genova.

Boni, P., Mosna, S. and Vanossi, M., 1968. La "Pietra di Finale" (Liguria Occidentale). Atti Ist. Geol. Univ. Pavia, 18: 102-150.

Boschian, G. and Gabriele, M., 2007. Analisi mineralogicopetrografica degli impasti ceramici. In C. Tozzi, M.C. Weiss (eds.). Préhistoire et protohistoire de l'aire tyrrhénienne, Felici Editore, Ghezzano, 101-114.

Capelli, C., Cabella, R., Piazza, M. and Vitali, D., 2007a. La produzione di ceramica romana dell'atelier di Albinia (GR): nuovi dati archeometrici. In C. D'Amico (ed.). Atti del IV Congresso Nazionale di Archeometria, Pisa 1-3 febbraio 2006, Pàtron Editore, Bologna, 465-472.

Capelli, C., Mannoni T. and Starnini, E., 2006a. Tecniche produttive, materie prime e provenienza delle ceramiche preistoriche della Liguria. In Materie prime e scambi nella preistoria italiana. Atti della XXXIX Riunione Scientifica dell'Istituto Italiano di Preistoria e Protostoria, Firenze 2004, 1201-1208.

Capelli, C., Mannoni, T., Starnini, E. and Cabella, R., 2006 b. Le origini della produzione in Liguria: dati archeologici e mineralogico-petrografici integrati sulla ceramica preistorica e protostorica. In Atti del XXXVII Convegno Internazionale della Ceramica (“Albisola”), Savona 2004, All'Insegna del Giglio, Firenze, 49-55.

Capelli, C., Starnini, E. and Cabella, R., 2007b. Il contributo delle analisi minero-petrografiche allo studio della circolazione di ceramiche nel Neolitico Antico: il caso della Caverna delle Arene Candide (Finale Ligure, SV). In C. D'Amico (ed.). Atti IV Congresso Nazionale di Archeometria, Scienza e Beni Culturali, Pisa 1-3 febbraio 2006, Pàtron Editore, Bologna, 413-419.

Capelli, C., Starnini, E., Cabella, R. and Piazza, M., 2006 c. Archaeometric research on the Early Neolithic pottery production in Liguria (Northern Italy): preliminary data from San Sebastiano di Perti (Savona). ArcheoSciences (Revue d'Archéométrie), 30: 89-94.

Conticelli, S., Manetti, P., Peccerillo, A. and Santo, A., 1986. Caratteri petrologici delle vulcaniti potassiche italiane: considerazioni genetiche e geodinamiche. Memorie della Società Geologica Italiana, 35: 775-783.

Cortesogno, L., Gaggero, L. and Molli, G., 1994. Ocean floor tectono-metamorphic evolution in the Piedmont-Ligurian Jurassic basin: a review. Memorie della Società Geologica Italiana, 48: 151-163.

Cultrone, G., Rodriguez-Navarro, C., Sebastian, E., Cazalla, O. and De La Torre, M.J., 2001. Carbonate and silicate phase reactions during ceramic firing. European Journal of Mineralogy, 13: 621-634.

Del Lucchese, A., 1996. Riparo di Pian del Ciliegio (Finale Ligure, Savona). In R. Maggi, F. Martini, L. Sarti (eds.). Guide Archeologiche. Preistoria e Protostoria in Italia, 6, Toscana e Liguria, UISPP, A.B.A.C.O., Forlì, 199-205.

Del Lucchese, A. (ed.), in press. Il Riparo di Pian del Ciliegio (Finale Ligure-SV). Quaderni del Museo Archeologico del Finale, 5.

Ferraris, M. and Ottomano, C., 1997. Pottery analyses. In R. Maggi, E. Starnini, B.A. Voytek (eds.). Arene Candide: a functional and environmental assessment of the Holocene sequence (excavations Bernabò Brea-Cardini 1940-50), Memorie dell'Istituto Italiano di Paleontologia Umana 5, Roma, 339-348.

Giammarino, S., Giglia, G., Capponi, G., Crispini, L. and Piazza, M., 2002. Carta Geologica della Liguria - Scala 1:200000. Lab. Cartografia digitale e GIS del Dip. Sci. Terra Univ. Siena, L.A.C., Firenze.

Giuggiola, O. and Imperiale, G., 1970. Il Finalese. Contributi di studio per un parco naturale. Italia Nostra, sez. di Savona, 25-44.

Laviano, R. and Muntoni, I., 2006. Provenance and technology of Apulian Neolithic pottery. In M. Maggetti, B. Messiga (eds.). Geomaterials in Cultural Heritage, Geological Society special publication 257, London, 49-62.

Menchelli, S., Cabella, R., Capelli, C., Pasquinucci, M. and PicCHI, G., 2007. Anfore dell'Etruria settentrionale costiera in età romana: nuovi dati alla luce delle recenti indagini archeologiche ed archeometriche. In Vitali D. (ed.). Atti del Seminario Internazionale: Le fornaci e le anfore di Albinia. Primi dati su produzioni e scambi dalla costa tirrenica al mondo gallico, Ravenna 6-7 maggio 2006, Bologna, 141-150.

Muntoni, I., 2002. La tecnologia della ceramica impressa, in M.A. Fugazzola Delpino, A. Pessina, V. Tiné (eds.), Le ceramiche impresse nel Neolitico Antico. Italia e Mediterraneo, Studi di Paletnologia I, Istituto Poligrafico e Zecca dello Stato, Roma, 231-250.

NonZa-Micaelli, A., 2007. Approvisionnement et traitement des matières premières argileuses durant le Néolithique en Corse et en Toscane, in C. Tozzi, M.C. Weiss (eds.), Préhistoire et protohistoire de l'aire tyrrhénienne, Felici Editore, Ghezzano, 253-260.

Spataro, M., 2002. The first farming communities of the Adriatic: pottery production and circulation in the early and middle Neolithic, Quaderni della Società per la Preistoria e Protostoria della Regione Friuli Venezia Giulia, Trieste, Edizioni Svevo.

VAnossi, M. (ed.), 1991. Guide Geologiche Regionali - Alpi Liguri, Società Geologica Italiana, BeMa., Milano.

Vanossi, M., Cortesogno, L., Galbiati, B., Messiga, B., Piccardo, G.B. and Vannucci, R., 1984. Geologia delle Alpi Liguri: dati, problemi, ipotesi. Memorie della Società Geologica Italiana, 28: 5-75. 